\title{
Pemilihan Saham Syariah yang Efisien untuk Pembentukan Portofolio Optimal
}

\author{
${ }^{1 *}$ Nur Rachmat Arifin, ${ }^{2}$ Taufik Nugroho, ${ }^{3}$ Raditya Sukmana \\ ${ }^{1,2,3}$ Faculty of Economics and Business, Universitas Airlangga, Surabaya, Indonesia \\ *Email korenpondensi: nur.rachmat.arifin-2018@ pasca.unair.ac.id
}

\begin{abstract}
Analysis of optimal portfolio allows investors to analyze appropriate to minimize the risks accepted by the objective of maximizing profit with the same risk among existing stocks. Data Envelopment Analysis (DEA) is used to determine the stocks with the efficient performance based on ratio analysis. Having selected some stocks efficient formation of optimal portfolio is then performed with a single index models and determined how much the proportion of funds invested in each stock. The sample data used are stocks in ISSI 2012-2017. Based on the analysis of efficiency as a candidate portfolio models used DEA - CCR and DEA - BCC generate 16 efficient stocks that forming the candidate portfolio. After the analysis of all 18 stocks that efficiently obtained 6 stocks forming the optimal portfolio, The results of the study concluded that the portfolio with the DEA model and the Single Index Model produced higher returns compared to the return of the Jakarta Islamic Index (JII). In addition, the performance portfolio also shows that this is only for CSPI and ISSI.
\end{abstract}

Keywords: Portfolio, DEA, Single Index ModeL

Saran sitasi: Arifin, N. R., Nugroho, T., \& Sukmana, R. (2019). Pemilihan Saham Syariah yang Efisien untuk Pembentukan Portofolio Optimal. Jurnal Ilmiah Ekonomi Islam, 5(03), 307-316. doi: http://dx.doi.org/10.29040/jiei.v5i3.643

DOI: http://dx.doi.org/10.29040/jiei.v5i3.643

\section{Pendahuluan}

Salah satu hal yang terpenting sebelum membentuk suatu portofolio saham adalah menyeleksi sekuritas atau saham yang akan membentuk portofolio tersebut. Dalam menyeleksi saham tidak hanya mempertimbangkan return dan risikonya, tetapi juga perlu mempertimbangkan aspek fundamental yang mempengaruhi kinerja saham tersebut (Zamazami \& Leila, 2014). Konsep ini didasarkan pada studi (Brigham \& Houston, 2007), yang menunjukkan bahwa rasio keuangan di laporan keuangan akan mempengaruhi harga saham. Bahkan, angka-angka dalam laporan keuangan mencerminkan kinerja dan efisiensi perusahaan. (Chen, 2008) dalam penelitiannya menunjukkan bahwa investasi pada perusahaan yang lebih efisien, menghasilkan return yang lebih baik. Tetapi untuk mengevaluasi efisiensi perusahaan dengan input dan output yang berbeda cukup sulit untuk dilakukan. Oleh karena itu, untuk mengevaluasi efisiensi perusahaan bisa menggunakan model Data Envelopment Analysis (DEA). Model DEA yang dikembangkan oleh (Cooper \& Rhodes, 1978) dapat secara obyektif menggabungkan beberapa input dan output dari suatu entitas menjadi ukuran tunggal efisiensi decision making unit (DMU) secara keseluruhan.

Dalam menganalisis saham-saham terbaik untuk pembentukan portofolio bisa menggunakan metode Data Envelopment 
Analysis (DEA) dengan menyeleksi sahamsaham mana yang paling efisien. Sehingga dalam membentuk portofolio nantinya tidak harus menghitung semua saham yang ada di suatu bursa efek tertentu, melainkan hanya menghitung saham-saham yang efisien berdasarkan hasil dari metode Data Envelopment Analysis (DEA). Oleh sebab itu, DEA seharusnya dapat digunakan untuk menyeleksi atau menyaring saham-saham dalam pembentukan portofolio dengan return yang maksimal.

Kemudian, dalam membentuk portofolionya investor akan dihadapkan pada berbagai pilihan kombinasi aktiva berisiko maupun bebas risiko yang dapat dimasukan kedalam portofolionya. Seluruh kemungkinan portofolio yang dapat dibentuk tersebut jumlahnya bisa sangat besar dan bahkan tak terbatas. Jika investor adalah rasional, maka mereka akan memilih portofolio yang optimal, yakni "portofolio dengan kombinasi return ekspektasian dan risiko yang terbaik" (Hartono, 2010). Perhitungan untuk menentukan portofolio optimal akan lebih mudah jika hanya didasarkan pada sebuah angka yang dapat menentukan apakah suatu sekuritas dapat dimasukan ke dalam portofolio optimal tersebut. (Hartono, 2010). Teknik penentuan efficient frontier yang sederhana untuk tujuan pembentukan portofolio optimal seperti itu salah satunya diformulasikan oleh (Arifin, Arga, \& Sitohang, 2014) dalam model Single Index Model. Single Index Model dikemukakan pertama kali oleh William Sharpe pada tahun 1963 yang didasarkan pada pengamatan bahwa harga dari suatu sekuritas berfluktuasi searah dengan indeks harga pasar (Hartono, 2010). Model ini nantinya akan dapat menentukan apakah suatu saham masuk ke dalam portofolio optimal atau tidak menggunakan suatu kriteria ranking yang unik. Saham akan diurutkan berdasarkan kinerja yang diukur menggunakan suatu rasio ekses return terhadap risiko, sehingga jika suatu saham masuk ke dalam portofolio optimal, maka saham dengan ranking yang lebih tinggi juga akan masuk ke dalam portofolio.

Oleh karena itu, pada penelitian ini digunakan pendekatan Data Envelopment Analysis (DEA) untuk menentukan saham-saham yang efisien, sehingga dapat dijadikan pertimbangan dalam pembentukan portofolio. Setelah terpilih beberapa saham efisien selanjutnya dilakukan pembentukan portofolio optimal dengan Single Index Model dan bisa ditentukan berapa banyak proporsi dana yang diinvestasikan pada masing-masing saham dalam satu portofolio yang optimal.

Penelitian mengenai analisis saham-saham dengan pendekatan DEA juga pernah dilakukan oleh (Chen, 2008) Penelitiannya menggunakan dua model DEA untuk mengevaluasi efisiensi perusahaan dan membangun portofolio dengan memilih saham dengan efisiensi tinggi. Variabel DEA yang digunakan dalam penelitian tersebut adalah average equity, average asset, dan sales cost sebagai variabel input, serta revenues, operating profit dan net income sebagai variabel output. Hasil penelitian tersebut menunjukkan bahwa efek "size firm" tampaknya tidak pantas sebagai strategi pemilihan saham di pasar saham Taiwan. Namun, portofolio dibangun oleh model DEA masih memperlihatkkan hasil return yang superior daripada return rata-rata industri.

Begitu pula yang dilakukan oleh Werastuti (2014) yang juga melakukan penelitian pembentukan portofolio optimal dari sahamsaham LQ-45 dengan menggunakan Data Envelopment Analysis (DEA) dan Single Index Model. Variabel input yang digunakan dalam DEA adalah standar deviasi, Raw Beta (Beta), Debt to Equity Ratio (DER), dan Price to Earning Ratio (PER). Sedangkan untuk variabel outputnya adalah return, Pertumbuhan per Share (EPS), Book Value (BV), Price to Book Value (PBV), Return On Equity (ROE), Return On Assets ROA, dan Net Profit Margin (NPM). Hasil Penelitian tersebut, dari 11 saham yang efisien, terpilih 3 saham untuk dijadikan portofolio optimal.

\section{Metode Penelitian}

2.1 Penentuan Objek 
Sampel yang digunakan dalam penelitian ini adalah perusahaan-perusahaan yang masuk dalam Indeks Saham Syariah Indonesia (ISSI). Sampel diambil dengan metode purposive sampling dengan kriteria perusahaan yang konsisten masuk dalam ISSI dari Januari 2012 sampai dengan Desember 2017. Serta saham syariah yang masuk dalam daftar lima (5) kapitalisasi pasar terbesar per sektor dan masuk daftar 100 kapitalisasi pasar terbesar di Indeks Harga Saham Gabungan (IHSG). Berdasarkan kriteria di atas, saham yang masuk dalam sampel penelitian ini sebanyak 32 saham atau emiten dari total 293 saham syariah yang konsisten di Indeks Saham Syariah Indonesia (ISSI) selama periode 2012-2017.

\subsection{Pengumpulan Data}

Pada tahap ini dilakukan pengumpulan data. Data yang diperlukan dalam penelitian ini adalah berupa data sekunder yaitu: data harga saham bulanan emiten pada saat closing price, ,Indeks Harga Saham Gabungan (IHSG) selama periode Januari 2012 sampai dengan Desember 2017, data tingkat imbal hasil Sertifikat Bank Indonesia Syariah (SBIS), serta data Laporan Keuangan Tahunan (Annual Financial Report) yang telah diaudit per 31 Desember 2012 sampai 2017.

\subsection{Penentuan Variabel Input-Output}

Variabel-variabel input-output yang digunakan dalam penelitian ini meliputi :

1. Standar deviasi yang merupakan alat statistik yang digunakan untuk mengetahui besarnya penyimpangan yang terjadi antara expected return dengan actual return. Untuk menghitung nilai standard deviasi digunakan persamaan :

$$
\sqrt{\frac{\sum_{t=1}^{n}(R i t-E(R i))^{2}}{N}} .
$$

$\sigma i \quad$ : standar deviasi saham i

Rit : return saham $i$ periode $t$

(Ri) : expexted return saham $i$

$N \quad$ : periode pengamatan

$$
R_{i t}=\frac{D_{i t}}{P_{i t-1}}+\frac{P_{i t-} P_{i t-1}}{P_{i t-1}}
$$

Rit : return saham $i$ periode $t$

Pit : harga saham $i$ periode $\mathrm{t}$

Pit-1 : harga saham $i$ periode $t-1$

Dit : dividen saham $i$ periode $\mathrm{t}$

$R_{i t}=\frac{\sum R_{i t}}{n}$

(Ri) : expexted return saham $i$

Rit : return saham $i$ periode $t$

$n \quad$ : periode pengamatan

2. Beta (Raw Beta) sebagai ukuran relatif dari risiko yang merupakan risiko sistematis. Beta mengukur sensitifitas saham terhadap pergerakan pasar. Sebagai ukuran risiko relatif, beta berguna sebagai pembanding risiko sistematis saham yang berbeda dan digunakan oleh investor untuk menilai risiko suatu saham. Saham dengan beta tinggi (rendah) dikatakan sebagai sekuritas yang berisiko tinggi (rendah). Untuk menghitung koefisien risiko beta digunakan persamaan:

$B_{i}=\frac{\operatorname{cov}\left(R_{i} R_{m}\right)}{\sigma_{m}}$

$\beta i \quad$ : koefisien risiko saham ke-i

$\sigma m$ : varian pasar

$\mathrm{Rm}$ : return pasar (diwakili oleh Indeks Harga Saham Gabungan)

$R_{m}=\frac{\left.I H S G_{t}-I H S G_{t-1}\right)}{I H S G_{t-1}}$

Adjusted Beta adalah hasil normalisasi nilai Raw Beta agar sesuai dengan karakteristik nilai beta saham yang baik, yaitu mendekati satu (Bodie et al, 2009). Rumus perhitungan Adjusted Beta :

adjusted $\beta=\frac{2}{3} x\left(\right.$ Raw $\beta+\frac{1}{3}$

3. DER (Debt-Equty Ratio) merupakan salah satu rasio dalam kelompok leverage ratio. Rasio ini menunjukkan seberapa jauh perusahaan dibiayai oleh pihak kreditur. Semakin tinggi nilai DER maka semakin besar pula dana yang diambil dari luar. Bila terjadi likuidasi maka hak kreditur akan dipenuhi terlebih dahulu baru kemudian hak pemegang saham. Rasio ini diukur dengan menggunakan rumusan sebagai berikut : 
DER $=\frac{\text { Total kewajiban } / \text { hutang }}{\text { Total ekuitas }}$

4. EPS (Earning Per Share) menunjukkan seberapa besar keuntungan yang dihasilkan oleh perusahaan untuk tiap lembar saham yang beredar. Untuk menghitung Earning Per Share digunakan rumusan sebagai berikut :

EPS $=\frac{\text { Laba setelah pajak }}{\text { Jumlah saham yang beredar }}$

5. PER (Price Earning Ratio) memberikan indikasi tentang jangka waktu yang diperlukan untuk mengembalikan dana pada tingkat harga saham dan keuntungan perusahaan pada suatu periode tertentu. Untuk menghitung PER digunakan rumusan sebagai berikut:

PER $=\frac{\text { Harga Saham }}{\text { EPS }}$

6. Return merupakan hasil dari dividend dan capital gain (loss). Untuk menghitung return digunakan persamaan (3.2).

7. BV (Book Value Per Share) menggambarkan perbandingan total modal (ekuitas) terhadap jumlah saham. Untuk menghitung BV digunakan rumusan sebagai berikut:

$B V=\frac{\text { Total ekuitas }}{\text { Jumlah sahamyang beredar }}$.

8. PBV (Price Book Value Ratio) menggambarkan seberapa besar pasar menghargai nilai buku saham suatu perusahaan.

$P B V=\frac{\text { Harga saham }}{\text { Nilai buku perlembar }}$

9. ROE (Return On Equity) merupakan indikasi tingkat pengembalian investasi yang dapat dicapai oleh suatu perusahaan dengan modal yang diinvestasikan oleh investor. ROE sering dipakai juga sebagai alat ukur efisiensi perusahaan. Semakin besar nilai ROE maka semakin efisien perusahaan tersebut dalam menggunakan modal sendiri untuk menghasilkan laba bersih bagi investor. Untuk menghitung ROE digunakan rumusan sebagai berikut :
ROE $=\frac{\text { Labasetelah pajak }}{\text { Total ekwitas }} \times 100$

10. ROA (Return On Asset) menunjukkan seberapa banyak laba bersih yang bisa diperoleh dari seluruh kekayaan yang dimiliki perusahaan, karena itu dipergunakan angka laba setelah pajak dan (rata-rata) kekayaan perusahaan. Untuk menghitung ROA digunakan rumusan sebagai berikut :

ROA $=\frac{\text { Laba setelah pajak }}{\text { Total aset }} \times 100 \%$

11. NPM (Net Profit Margin) adalah rasio tingkat profitabilitas yang dihitung dengan cara membagi keuntungan bersih dengan total penjualan. Rasio ini menunjukkan keuntungan bersih dengan total penjualan yang diperoleh dari setiap penjualan. Untuk menghitung NPM digunakan rumusan sebagai berikut :

NPM $=\frac{\text { Labasetelahpajak }}{\text { Total Penjualan }} \times 100 \%$. . .

12. Undiserable Variable

13. Pada model Data Envelopment Analysis (DEA) terdapat kendala yang harus dipenuhi yaitu nilai-nilai dari input atau output harus lebih besar sama dengan nol. Namun pada kenyataannya variabel beta dan return pada saham seringkali negatif. Pada kasus seperti ini variabel beta dan return dikatakan sebagai undiserable variable atau variabel yang tidak diinginkan. Terdapat beberapa teknik yang digunakan ketika ada undiserable variable pada model. Adler dan Golany (2001) mengatakan bahwa variabel yang digunakan pada DEA meningkat sebesar nilai yang paling negatif ditambah satu ketika diperlukan sehingga data menjadi positif. Perubahannya sebagai berikut :

$X=X+a$

dengan

$a=\{X\}+1$

Dari sebelas variabel tersebut yang termasuk variabel input adalah standar deviasi, adjusted beta, DER, dan PER. Sedangkan untuk variabel outputnya adalah return, EPS, BV, PBV, ROE, ROA, dan NPM. 


\subsection{Pemilihan Saham Syariah yang Efisien sebagai Kandidat Penyusun Portofolio} dengan Data Envelopment Analysis (DEA)

Adapun langkah-langkah yang digunakan untuk menentukan saham-saham yang efisien pembentuk portofolio adalah sebagai berikut :

1. Menghitung return dan expected return masing-masing saham dengan persamaan (2.2) dan (2.3).

2. Menghitung risiko masing-masing saham, dengan menggunakan standard deviasi dari masing-masing saham yang didapat dengan persamaan (2.1).

3. Menghitung koefisien risiko beta dan adjusted beta masing-masing saham dengan menggunakan persamaan (2.6).

4. Menghitung rasio-rasio seperti DER, EPS, BV, PBV, ROE, ROA, NPM, PER dengan rumusan yang sudah ada.

5. Menentukan nilai-nilai input dan output tiap Decision Making Units (DMU) yang digunakan dalam perhitungan DEA. DMU dalam penelitian adalah emiten yang menjadi objek penelitian.

6. Mengkonversi nilai input dan output nilai adjusted beta dan return dapat dikonversi dengan menggunakan persamaan (2.15) dan (2.16).

7. Mengolah model DEA-CCR dan DEA-BCC dengan software MAXDEA 6.1 untuk mendapatkan nilai efisiensi teknis dan skala pada setiap DMU.

\subsection{Pembentukan Portofolio Optimal dengan} Single Index Model

Setelah didapatkan saham-saham yang efisien dengan menggunakan metode Data Envelopment Analysis (DEA), langkah selanjutnya adalah membentuk portofolio optimal dari saham-saham yang efisien dengan Single Index Model yang konsep penghitungannya didasarkan pada model perhitungan (Elton, 1995):

1. Menghitung ERB (excess return to beta), yaitu selisih expected return dengan keuntungan bebas risiko yang didapatkan dari rata-rata imbal hasil Sertifikat Bank
Indonesia Syariah (SBIS) selama periode pengamatan. ERB adalah kelebihan keuntungan relative terhadap satu unit risiko yang tidak dapat didiversifikasikan yang diukur dengan beta. Dengan persamaan :

$E R B=\frac{R_{i}-R_{f}}{\beta_{\mathrm{i}}}$

$E R B$ : excess return to beta

$R i \quad$ : expected return berdasarkan single

index model untuk saham ke- $i$

$R f \quad$ : expected return aktiva bebas risiko

$\beta i \quad$ : adjusted Beta saham ke- $i$

2. Menghitung Cut off rate (Ci), yaitu batasan untuk memisahkan saham-saham apa saja yang akan dimasukkan dalam portofolio optimal. Dengan menggunakan persamaan :

$C_{i}=\frac{{ }_{m^{2} \Sigma} \frac{\left(R_{i}-R_{f}\right) \beta_{i}}{\sigma_{g L^{2}}}}{1+\sigma_{m^{2}} \Sigma\left(\frac{\beta_{i} i^{2}}{\sigma_{e i^{2}}}\right)}$.

Ci : cut off rate saham ke- $i$

$\sigma m 2$ : variansi pasar dari IHSG

oei2 : nilai varian error saham ke- $i$

3. Menghitung proporsi dana tiap-tiap saham, yaitu dengan menghitung besarnya

presentase pada masing-masing saham yang terpilih didalam pembentukan portofolio optimal, dengan persamaan :

$W_{i}=\frac{x_{i}}{\sum_{i}^{n}=1 x_{i}}$.

$X_{i}=\frac{\beta_{i}}{\sigma_{e i^{2}}}(E R B-C)$

dimana :

$W i \quad$ : besarnya presentase dana yang diinvestasikan pada saham ke- $i$

$X i \quad$ : proporsi saham ke-i

$C * \quad$ : nilai $C i$ yang paling besar

4. Menghitung return dan expected return portofolio, dengan persamaan

$R_{p i}=\sum_{i=1}^{n} W_{i} R_{i}$

$R p \quad:$ return portofolio

$(R p)=\alpha p+\beta p$

$R p$

dimana :

$a_{p}=\sum_{i=1}^{n} W_{i} a_{i}$

$\beta_{p}=\sum_{i=1}^{n} W_{i} \beta_{i}$ 
5. Menghitung risiko portofolio, dengan persamaan :

$\sigma_{p^{2}}=\beta_{p^{2}} \sigma_{m^{2}}+\sum_{i=1}^{n} W_{1} 2 \sigma_{a i} 2$

$\sigma_{p}=\sqrt{\beta_{p^{2}}} \sigma_{m^{2}}+\sum_{i=1}^{n} W_{1^{2}} \sigma_{e i^{2}}$

dimana :

$\sigma p 2$ : varian portofolio

$\sigma p \quad$ : standar deviasi portofolio

\section{Hasil dan Pembahasan}

\subsection{Penentuan Saham untuk Kandidat Portofolio dengan DEA}

Untuk menentukan saham-saham syariah mana yang dijadikan sebagai kandidat portofolio optimal, dilakukan dengan melihat saham mana saja yang efisien dengan menggunakan metode Data Envelopment Analysis (DEA). Pengukuran efisiensi kinerja menggunakan metode DEA memerlukan variabel input dan output. Sahamsaham tersebut dihitung efisiensinya dengan menggunakan DEA berdasarkan 11 variabel, empat variabel input dan tujuh variabel output. Variabel input DEA terdiri dari standar deviasi, adjusted beta, DER dan PER. Sedangkan variabel output terdiri dari return, EPS, BV, PBV, ROE, ROA, dan NPM. Penggunaan variabel input dan output ini sudah cukup mewakili preferensi investor dalam menentukan portofolio, yaitu berdasarkan return, risiko dan aspek fundamental kinerja keuangan.

Nilai efisiensi teknis constant return to scale (CRS) (TE-CCR) didapat dengan menyelesaikan model DEA-CCR (Charnes, Cooper, Rhodes) dan nilai efisiensi teknis variable return to scale (VRS) (TE-VRS) didapat dengan menyelesaikan model DEA-BCC (Banker, Charnes, Cooper). Sedangkan skala efisiensi (SE) didapat dari perbandingan TE-CRS dengan TE-VRS. Untuk menghitung nilai efisiensi dengan meode DEA digunakan Software MAXDEA 6.1. Hasil perhitungan nilai efisiensi teknis pada model DEA-CCR, model DEA BCC serta skala efisiensi ditunjukkan pada Tabel 8.

Nilai efisiensi teknis untuk masing-masing Decision Making Unit (DMU) pada model DEACCR dan DEA-BCC menunjukkan efisien atau tidaknya kinerja suatu DMU. Suatu DMU dikatakan efisien jika nilai efisiensinya sama dengan satu jika kurang dari satu maka DMU dikatakan tidak efisien. Dalam penelitian ini Decision Making Unit (DMU) merupakan saham yang akan diseleksi efisiensinya.

Tabel 1 Nilai Efesiensi Masing-Masing Saham

\begin{tabular}{|l|r|r|l|l|r|r|l|l|r|r|r|}
\hline \multirow{2}{*}{ DMU } & \multicolumn{2}{|c|}{ Effciency Score } & \multirow{2}{*}{ SE } & \multirow{2}{*}{ DMU } & \multicolumn{2}{|c|}{ Effciency Score } & \multirow{2}{*}{ SE } & \multirow{2}{*}{ DMU } & \multicolumn{2}{|c|}{ Effciency Score } & \multirow{2}{*}{ SE } \\
\cline { 2 - 6 } & CRS & VRS & & & CRS & VRS & & & CRS & VRS & \\
\hline AALI & 1 & 1 & 1.000 & INDF & 0.901 & 0.984 & 0.916 & PWON & 0.945 & 0.982 & 0.962 \\
\hline ADRO & 0.644 & 0.893 & 0.721 & INTP & 1 & 1 & 1.000 & SIMP & 0.801 & 0.913 & 0.877 \\
\hline AKRA & 0.773 & 0.886 & 0.872 & ITMG & 1 & 1 & 1.000 & SMCB & 0.786 & 0.924 & 0.850 \\
\hline ASII & 1 & 1 & 1.000 & JSMR & 0.863 & 0.944 & 0.914 & SMGR & 1 & 1 & 1.000 \\
\hline AUTO & 0.905 & 0.967 & 0.936 & KLBF & 1 & 1 & 1.000 & TLKM & 1 & 1 & 1.000 \\
\hline BMTR & 0.756 & 0.936 & 0.808 & LPKR & 0.797 & 0.904 & 0.881 & UNTR & 1 & 1 & 1.000 \\
\hline BSDE & 1 & 1 & 1.000 & LSIP & 1 & 1 & 1.000 & UNVR & 1 & 1 & 1.000 \\
\hline CPIN & 0.794 & 0.972 & 0.817 & MNCN & 1 & 1 & 1.000 & WIKA & 0.704 & 0.883 & 0.798 \\
\hline GEMS & 1 & 1 & 1.000 & MYOR & 0.549 & 0.922 & 0.596 & INCO & 0.939 & 1 & 0.939 \\
\hline ICBP & 0.917 & 1 & 0.917 & PGAS & 1 & 1 & 1.000 & PTBA & 1 & 1 & 1.000 \\
\hline
\end{tabular}

Sumber : Data sekunder yang diolah,MaxDEA 6.1 dan Ms,Excel

Dari tabel diatas terlihat bahwa DMU yang telah beroperasi secara optimal $(\mathrm{SE}=1)$ ada 15 DMUyaitu AALI, ASII, BSDE, GEMS, INTP, ITMG, KLBF, LSIP, MNCN, PGAS, PTBA, SMGR, TLKM, UNTR dan UNVR. Kelima belas saham teresbut yang akan dijadikan sebagai kandidat portofolio optimal.

\subsection{Pembentukan Portofolio Optimal dengan Single Index Model}


Setelah diperoleh saham-saham yang efisien dengan menggunakan metode DEA-CCR dan DEA-BCC, tahap selanjutnya adalah perancangan portofolio. Perancangan portofolio dilakukan dengan menggunakan Single Index Model. Single Indeks Model merupakan juga digunakan untuk menentukan besarnya proporsi saham.

\subsubsection{Perhitungan Excesss Return to Beta (ERB)}

Pada pengolahan data dengan menggunakan Single Index Model yang pertama kali dilakukan adalah menghitung nilai excess return to beta (ERB) dengan persamaan (2.17). Saham dengan nilai ERB negatif berarti saham tersebut mempunyai tingkat pengembalian saham yang masih di bawah tingkat pengembalian bebas risiko. Portofolio optimal akansm terdiri dari saham-saham yang mempunyai nilai ERB yang tinggi. Pada tabel dibawah berikut ini adalah contoh dari hasil perhitungan ERB. Pada Single Index Model, langkah pertama yang dilakukan adalah menghitung nilai ERB (excess return to beta). Untuk memenuhi perhitungan ERB diperlukan data tingkat pengembalian aset bebas risiko yang dalam penelitian ini digunakan rata-rata tingkat imbalan SBIS bulanan selama periode penelitian dan didapatkan rata-rata tingkat imbalan SBIS bulanan sebesar $0.676 \%$.

\section{Tabel 2 Hasil Pehitungan Excess Return to} Beta (ERB)

\begin{tabular}{|c|c|c|r|}
\hline Emiten & ERB & Emiten & \multicolumn{1}{|c|}{ ERB } \\
\hline BSDE & 0.091447 & PGAS & 0.011251 \\
\hline KLBF & 0.009401 & TLKM & 0.01371 \\
\hline UNTR & -0.00057 & UNVR & 0.013786 \\
\hline AALI & -0.11895 & INTP & -0.0057 \\
\hline ASII & -0.00217 & ITMG & -0.01843 \\
\hline GEMS & -0.01683 & MNCN & 0.023149 \\
\hline
\end{tabular}

Sumber: Data sekunder yang diolah, Ms Excel

Dari hasil perhitungan ERB, didapatkan bahwa ada 6 emiten yang ERBnya bernilai positif yaitu BSDE,KLBF,PGAS,TLKM,UNVR dan MNCN. Sdeangkan ada 9 emiten yang ERBnya bernilai negative yaitu AALi, ASII, GEMS, INTP, ITMG, LSIP, PTBS, SMGR dan UNTR. Sehingga emiten yang niai ERBnya negative otomatis dikeluarjan dari daftar kandidat portofolio optimal.

\subsubsection{Perhitungan Cut Off Rate (Ci)}

Setelah di peroleh nilai ERB yang bernilai positif kemudian dicari nilai Cut off Rate (Ci) dengan menggunakan persamaan (3.18). Cut Off Rate (Ci) adalah batasan yang digunakan untuk memisahkan saham-saham apa saja yang akan dimasukkan dalam portofolio optimal. Pada tabel dibawha ini menunjukkan nilai Cut off Rate dari emiten yang memiliki nilai ERB bernilai positif.

Tabel 3 Hasil Perhitungan Cut Off Rate (Ci)

\begin{tabular}{|c|c|c|c|}
\hline Emiten & $\mathrm{Ci}$ & Emiten & $\mathrm{Ci}$ \\
\hline BSDE & 0.000115 & TLKM & 0.003286 \\
\hline KLBF & 0.002104 & UNVR & 0.001299 \\
\hline PGAS & 0.000177 & MNCN & 0.000183 \\
\hline
\end{tabular}

Sumber: Data sekunder yang diolah,MS.Excell

Pada tabel di atas nilai $\mathrm{Ci}$ terbesar yaitu 0.003286. Nilai Ci terbesar tersebut menjadi $C^{*}$ (Cut Off Point) yang akan digunakan sebagai batasan suatu saham masuk dalam portofolio. Emiten yang nilai ERBnya lebih besar dari nilai C* (Cut Off Point), maka akan masuk dalam komponen portofolio optimal. Dari tabel diats dapat diketahui bahwa ada enam saham yang memenuhi kriteria untuk masuk ke dalam pembentukan portofolio yang optimal yaitu BSDE, KLB, PGAS, TLKM, UNVR, dan MNCN.

\subsubsection{Penentuan Proporsi Dana}

Setelah mengetahui sembilan saham yang terpilih untuk masuk ke dalam pembentukan portofolio yang optimal, selanjutnya menentukan proporsi $(\mathrm{W} i)$ yang diinvestasikan pada masingmasing saham di dalam portofolio tersebut dengan menggunakan persamaan (3.19) dan (3.20). Besarnya proporsi dana yang diinvestasikan pada masing-masing saham di dalam portofolio ditunjukan pada tabel dibawah

Tabel 4 Perhitungan Proporsi Dana (Wi)

\begin{tabular}{|c|c|c|c|c|c|}
\hline Emiten & $\mathrm{Xi}$ & $\mathrm{Wi}$ & Emiten & $\mathrm{Xi}$ & $\mathrm{Wi}$ \\
\hline BSDE & 0.678242 & $11.01 \%$ & TLKM & 2.373885735 & $38.53 \%$ \\
\hline KLBF & 1.20661 & $19.59 \%$ & UNVR & 1.325049479 & $21.51 \%$ \\
\hline PGAS & 0.25227 & $4.09 \%$ & MNCN & 0.324480192 & $5.27 \%$ \\
\hline
\end{tabular}

Sumber: Data sekunder yang diolah,Ms Excel 
Dari hasil perhitungan diata, besarnya presentase proporsi dana untuk setiap saham dalam portofolio adalah PT Bumi Serpong Damai Tbk (BSDE) sebesar $11.01 \%$, PT Kalbe Farma Tbk (KLBF) sebesar 19.59\%, PT Perusahaan Gas Negara (persero)Tbk (PGAS) sebesar $4.09 \%$. PT Telekomunikasi Indonesia Tbk (TLKM) sebesar $38.53 \%$, PT Unilever Indonesia Tbk (UNVR) sebesar $21.51 \%$ dan PT Media Nusantara Citra Tbk (MNCN) sebesar $5.27 \%$.

\subsubsection{Perhitungan expected Return dan Resiko Portofolio}

Setelah menentukan proporsi dana masingmasing saham pembentuk portofolio, maka dapat dihitung expected return portofolio dengan persamaan (2.21) dan juga dapat dihitung risiko portofolio dengan persamaan (2.26). hasil perhitungan expected return tersebut ditunjukan pada tabel dibawah.

Tabel 5 Perhitungan Expected return Portofolio

\begin{tabular}{|c|c|c|c|}
\hline Saham & $\mathrm{Wi}$ & $\mathrm{R}(\mathrm{p})$ & Beta $(\mathrm{p})$ \\
\hline BSDE & $11 \%$ & $0,183 \%$ & 0,011882 \\
\hline KLBF & $20 \%$ & $0,310 \%$ & 0,188818 \\
\hline MNCN & $5 \%$ & $0,075 \%$ & 0,016969 \\
\hline PGAS & $4 \%$ & $0,043 \%$ & 0,013614 \\
\hline TLKM & $39 \%$ & $0,743 \%$ & 0,351768 \\
\hline UNVR & $22 \%$ & $0,306 \%$ & 0,116913 \\
\hline \multirow{2}{*}{ Portofolio } & $100 \%$ & $1,660 \%$ & 0,699965 \\
\cline { 2 - 4 } & & $19,92 \%$ & \\
\hline \multirow{2}{*}{ Sumber: Data }
\end{tabular}

Sumber: Data sekunder yang diolah,Ms Excel

Dari tabel diatas emnunjukan bahwa portofolio yang dibentuk dari enam saham syariah tersebut memberikan tingkat pengembelian (expexted return) sebesar 1,660\% per bulan atau $19,92 \%$ per tahun. Return yang dihasilkan pada tabel diatas merupakan rata-rata return realisasikan dengan besaran proporsi dana yang ditanamkan pada portofolio. Nilai resiko sistematis relative terhadap resiko pasar (beta) portofolio tersebut sekitar 0.7. selain itu dengan menggunakan persamaan $(3,36)$ maka didapatkan nilai standar deviasi atau resiko portofolio tersebut sebesar 0,03184996 atau 3,18\%.

\subsubsection{Evaluasi Kinerja Portofolio}

Untuk melihat lebih lanjut seberapa baik kinerja portofolio yang dihasilkan, maka perlu dibandingkan juga dengan indeks saham lain. Sekaligus peneliti ingin mencoba membandingkan kinerja portofolio tersebut, tidak hanya dengan indeks saham syariah tetapi juga dengan indeks saham konvensional. Dengan asumsi bahwa kinerja portofolio tidak hanya lebih baik dari indeks saham syariah, tetapi juga lebih baik dari indeks saham konvensional. Sehingga, indeks saham lain yang dijadikan tolak ukur adalah Jakarta Islamic Index (JII), Indeks Harga Saham Gabungan (IHSG) dan Indeks Saham Syariah Indonesia (ISSI. Perbandingan kinerja portofolio dengan beberapa indeks saham tersebut, juga didasarkan pada perbandingan return bulanan selama periode 2012 sampai 2017 Hasil perbandingan kinerja antara portofolio dengan ketiga indeks saham tersebut ditunjukkan pada gambar dibawah ini.

Gambar 1. Grafik Perbandingan Kinerja Portofolio

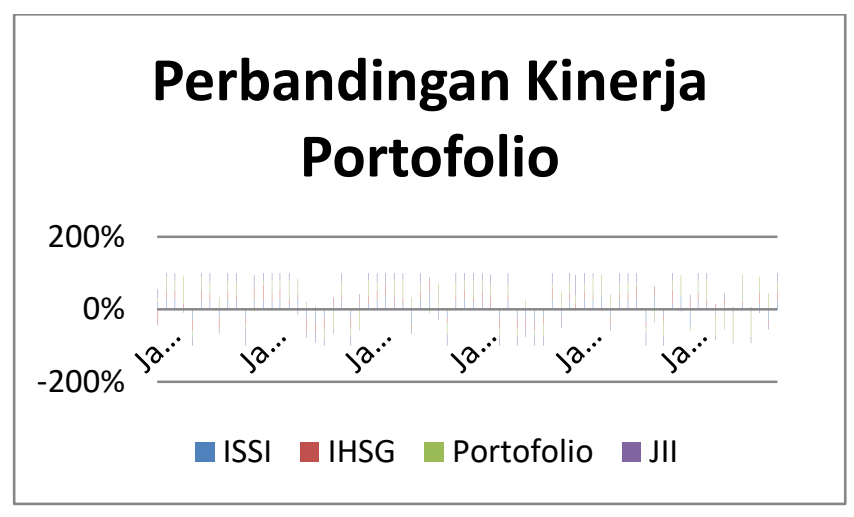

Sumber: Data return portofolio dan indeks yang diolah,Ms Excel

Pada gambar grafik diatas, menunjukan bahwa kinerja portofolio yang dihasilkan memang cenderung relatif lebih baik dari ketiga indeks saham yang lain. Pada garis tersebut garis portofolio (garis berwarna hijau)hampir selalu berada diatas garis indeks lain. Hal ini menunjukan bahwa return portofolio tersebut lebih baik dibandingkan ketiga indeks saham yang lain. Untuk lebih jelasnya gambardibawah menunjukan statistika deskriptif dari data perbandingan kinerja portofolio tersebut. 
Tabel 6 Statistika Deskriptif Perbandingan Kinerja Portofolio

\begin{tabular}{||c|c|c|c|c|c|}
\hline Variabel & $\begin{array}{c}\text { Total } \\
\text { account }\end{array}$ & Mean & Se Mean & St Dev & Variance \\
\hline ISSI & 60 & 0.005981 & 0.004792 & 0.037116 & 0.001378 \\
\hline IHSG & 60 & 0.004136 & 0.005027 & 0.038938 & 0.001516 \\
\hline Portofolio & 60 & 0.015642 & 0.006053 & 0.046884 & 0.002198 \\
\hline JII & 60 & 0.005035 & 0.00501 & 0.038805 & 0.001506 \\
\hline
\end{tabular}

Sumber:Data sekunder yang diolah di Ms,Excel

Dari tabel diatas, menunjukkan bahwa portofolio yang dihasilkan memiliki nilai mean return yang paling tinggi diantara ketiga indeks saham lain. Rata-rata return bulanan portofolio yang dihasilkan sebesar $1.56 \%$ jauh lebih tinggi dibandingkan dengan, ISSI (0.60), JII $(0.50 \%)$, dan IHSG $(0.41 \%)$. Hal itu menunjukkan secara statistik kinerja portofolio selama periode 2012 sampai 2017 lebih baik dibandingkan dengan ketiga indeks saham yang lain berdasarkan rata-rata return bulanannya. Tetapi untuk tingkat risikonya, indeks ISSI memiliki risiko yang paling rendah dengan nilai standar deviasi sebesar $3.71 \%$, paling rendah dibandingkan dengan JII (3.88\%), IHSG (3.8(\%), dan Portofolio (4.69).berdasarakan data statisitka diatas seperti kesimpulan pada pengujian hipotesis, bahwa hasil penelitian ini sejalan dengan hasil penelitian Chen (2008) dan Leivo dan Patari (2010) bahwa portofolio yang dihasilkan dengan Data Envelopment Analysis (DEA) menghasilkan return yang lebih superior dibandingkan rata-rata return pasar saham.

Dari ke 32 saham yang diteliti hanya 15 saham yang memiliki kinerja terbaik dari kedua model DEA dengan nilai skala efesiensi sama dengan 1 atau 100\% artimya saham-saham tersebut dapat secara optimal menggunakan input dan menghasilkan output yang sesuai. Saham-sahamtersebut diantaranya adalah AALI, ASII, BSDE, GEMS, INTP, ITMG, KLBF, LSIP, MNCN, PGAS, PTBA, TLKM, SMGR, UNTR dan UNVR. Kelima belas saham tersebut yang akan dijadikan sebagai kandidat portofolio optimal.

Setelah dilakukan analisis terhadap ke-15 saham yang efisien, maka dengan metode Single Index Model didapatkan 6 saham pembentuk portofolio optimal. enam saham yang memenuhi kriteria untuk masuk ke dalam pembentukan portofolio yang optimal tersebut adalah yaitu
BSDE, KLBF, PGAS, TLKM, UNVR dan MNCN. Sdeangkan ada 9 emiten yang ERBnya bernilai negative yaitu AALI, ASII, GEMS, INTP, ITMG, LSIP, PTBA, SMGR dan UNTR. Sehingga emiten yang niai ERBnya negative otomatis dikeluarjan dari daftar kandidat portofolio optimal

Adapun besarnya presentasi proporsi dana untuk setiap dana untuk setiap saham dalam portofolip adalah sebagai berikut:

1. PT Bumi Serpong Damai Tbk (11.01\%)

2. PT Kalbe Farma Tbk (19.59\%)

3. PT Media Nusantara Citra Tbk $(5.27 \%)$

4. PT Perusahan Gas Negara Tbk $(4.09 \%)$

5. PT Telekomunikasi Indonesia Tbk $(38.53 \%)$

6. PT Unilever Indonesia Tbk $(21.51 \%)$

Portofolio yang dibentuk dari saham syariah tersebut memberikan tingkat pengembalian (expected return) sebesar $1.56 \%$ per bulan atau $19.918 \%$ per tahun. Nilai risiko sistematis relatif terhadap risiko pasar (beta) portofolio tersebut sekitar 0.69 dengan nilai standar deviasi atau risiko portofolio sebesar 0.0468 atau sekitar 4.69\%. Hasil pengujian hipotesis penelitian menyimpulkan bahwa portofolio dengan model DEA dan Single Index Model menghasilkan return yang lebih tinggi dibandingkan dengan return Jakarta Islamic Index (JII). Bahkan dalam evaluasi kinerja portofolio tersebut, menunjukkan bahwa kinerja portofolio tersebut tidak hanya lebih baik dari indeks JII tetapi juga lebih baik daripada indeks IHSG dan ISSI.

\section{Kesimpulan}

Dari hasil evaluasi tersebut, dapat disimpulkan bahwa portofolio saham syariah yang dibentuk dengan metode DEA dan single Index Model dapat menghasilkan portofolio saham yang kinerjanya tidak hanya lebih baik dari indeks saham syariah, tetapi juga lebih baik dari indeks saham konvensional. Hal ini dapat dijadikan preferensi investor khususnya untuk investor muslim, bahwa cukup dengan berinvestasi di portofolio saham syariah pun bias menghasilkan kinerja yang lebih baik dari indeks saham konvensional. 


\section{Ucapan Terimakasih}

Peneliti merasa dan mengucapkan terima kasih kepada Allah SWT, terima kasih kepada dosen dan kolega yang membantu menyelesaikan penelitian ini secara optimal.

\section{Daftar Pustaka}

Arifin, Arga, B., \& Sitohang, S. (2014). Analisis

Portofolio Optimal Dengan Model Indeks

Tunggal Sebagai Dasar Penentuan

Keputusan Investasi. Jurnal Ilmu \& Riset

Manajemen, 3(8).

Adler N and B Golany.2001. "Evaluation of

Deregulated Airline Networks Using Data

Envelopment Analysis Combined with

Principal Component Analysis with an

Application to Western Europe." EJOR 132(2): 260-273.

Banker, R.D., Charnes, A., and Cooper, W.W. 1984, "Some Models for Estimating Technical and Scale Inefficiency in Data Envelopment Analysis",Management Science, 30 (9), 1078-92.

Brigham, F. Eugene and Philip R. Daves. 2004, Intermediate Financial Management, Eighth Edition, McGraw-Hill, Inc.New York.

Bursa Efek Indonesia. 2015. Data factbook Bursa Efek Indonesia tahun 2015. Bursa Efek Indonesia.

Bursa Efek Indonesia. 2015. Data Statistik Bursa Efek Indonesia tahun 2015. Bursa Efek Indonesia.

Brigham, \& Houston, J. F. (2007). Fundamentals of Financial Management. London: Thomson.

Chen, H.-H. (2008). Stock selection using data envelopment analysis. Industrial Management \& Data Systems, (9), 12551268.
Cooper, C., \& Rhodes. (1978). Measuring the Efficiency of Decision Making Units. European Journal of Operation Research, 6, 429-44.

Charnes, A., Cooper, W.W., and Rhodes, E. 1978, "Measuring the Efficiency of Decision Making Units", European Journal of Operation Research, 2, 6, 429- 44.

Elton, E. J. and M. J. G. (1995). Modern Portofolio Rheory and Insurement Analysis. Fith Edition,John Willey \& Sons, Inc Tronto.

Elton, Edwin J, Martin J, Gruber, and Manfred W. Padberg. 1976. "Simple Criteria for Optimal Portfolio Selection". The Journal of Finance, Volume XXXI No. 5 March 1976.

Elton Edwin J., and Martin J. Gruber. 1995. "Risk Reduction and Portfolio Size: An Analytical Solution". Journal of Business 50: 415-37

Hartono. (2010). Teori Portofolio dan Analisis sekuritas. In BPFE Yogyakarta.

Leivo, Timo, H. \& Patari, Eero J. 2010. "Ehancement of Value Portfolio Performance Using Data Envelopment Analysis". Studie in Economics and Finance. Vol.27, No.3. pp. 223-246.

Werastuti, Desak Nyoman Sri. 2014. "Pembentukan Portofolio Optimal melalui Pendekatan Efisiensi

Zamazami, \& Leila. (2014). portofolio selecton using dta enve;opment analysis (DEA) : Acase of slect indi invensmet companies. International Jornal of Currnt Research and Academic Review, (2), 50-55. 